\title{
ДЕЯТЕЛЬНОСТЬ БЕЛОРУССКОЙ ССР В ЕВРОПЕЙСКОЙ ЭКОНОМИЧЕСКОЙ КОМИССИИ (1954-1964 гг.)
}

\author{
С. Ф. Свилас \\ Белорусский государственный университет \\ Минск, Республика Беларусь
}

На основе документов Архива МИД Республики Беларусь впервые в историографии осуществлено комплексное исследование деятельности Белорусской ССР в Европейской экономической комиссии в годы хрущевской «оттепели», когда внешнеполитическая активность республики значительно усилилась. Будучи субъектом международных отношений, она продолжала оставаться при этом субъектом советской федерации.

Рассмотрено участие республики в сессиях ЕЭК и ее комитетов (по сельскому хозяйству, лесоматериалам, жилищному строительству, электроэнергии, газу, статистике), а также его результаты.

Особое внимание уделено усилиям Минска по формированию института постоянного представителя БССР при Европейском отделении ООН, роли государственных структур, прежде всего внешнеполитического ведомства, и их отдельных представителей в развитии международного экономического сотрудничества. Раскрыт механизм принятия решений по вопросам отношений с ЕЭК на республиканском уровне и влияние на него общесоюзного руководства.

Показаны место и роль ЕЭК в системе внешнеполитической деятельности БССР, определено значение этой структуры в деятельности республиканского МИД и международной активности других министерств и ведомств. На примере многосторонней дипломатии ЕЭК и участия в ней Белорусской ССР отражены особенности реализации принципа мирного сосуществования двух социально-политических систем в экономической сфере.

Определены проблемы, сложности и результаты участия республики в ЕЭК в указанный период. Подчеркнуто, что членство БССР в комиссии имело прежде всего прагматический характер, который преобладал над пропагандистским, однако в условиях холодной войны и советской экономической системы потенциал международного сотрудничества в экономической сфере реализовывался далеко не в полной мере.

Ключевые слова: СССР; Белорусская ССР; Европейская экономическая комиссия; хрущевская «оттепель»; международное экономическое сотрудничество; экономическая дипломатия; советская федерация; субъект советской федерации; субъект международных отношений; развивающиеся страны.

DOI: https://doi.org/10.33581/2311-9470-2019-7-46-70. 
Введение. Экономическая дипломатия является одним из приоритетов деятельности Республики Беларусь на международной арене и осуществляется с целью обеспечения экономической безопасности, а также достижения равного распределения экспортных поставок между тремя рынками - Евразийского экономического союза, Европейского союза и регионов «дальней дуги» (стран Азии, Африки и Латинской Америки).

Европейская экономическая комиссия была создана Экономическим и социальным советом ООН в 1947 г. для содействия общеевропейской экономической интеграции, при этом Белорусская ССР является членом комиссии со времени ее создания. В 2019 г. ЕЭК объединяет 56 государств, часть из которых входит в состав Европейского союза, а также не входящие в него государства Западной и Восточной Европы, участников СНГ, США, Канаду, Турцию, Израиль. Комиссия содействует экономическому сотрудничеству в Европе, укреплению экономической интеграции и торгово-экономических связей внутри региона, а также между регионом и остальным миром.

С момента вступления Белорусской ССР в ЕЭК накоплен полезный опыт, сформировались традиции сотрудничества республиканских государственных органов с этим авторитетным учреждением ООН. Многолетнее членство в комиссии способствует формированию позитивного имиджа Республики Беларусь на международной арене, служит одним из наиболее значимых каналов изучения и внедрения мировых инноваций в экономической сфере, стимулом к повышению эффективности экономической дипломатии и внешней политики страны.

Цель исследования состоит в выявлении особенностей и комплексной оценке влияния взаимодействия Белорусской ССР и ЕЭК в 1954-1964 гг. на внешнеполитическую деятельность и экономическое развитие республики.

Хронологические рамки исследования охватывают 19541964 гг. - годы хрущевской «оттепели», новый этап в развитии советской дипломатии, характеризовавшийся большей открытостью, реализмом и конструктивностью. Этот период был самым динамичным в истории внешнеполитической пропаганды СССР, в том числе посредством международного экономического сотрудничества, использовавшегося для решения не только пропагандистских, но и прагма- 
тических задач, что очевидно на примере членства Белорусской ССР в ЕЭК.

Актуальность проведенного исследования определяется значимостью ЕЭК в экономической дипломатии БССР и Республики Беларусь, а также отсутствием в белорусской историографии работ о предыстории их сотрудничества.

Публикация может быть использована для создания обобщающих научных трудов по истории внешней политики и дипломатии Беларуси, истории международных, в том числе экономических, отношений, в учебном процессе высших учебных заведений.

Методы исследования. При проведении исследования автор опирался на принципы объективности, историзма, системности и ценности в истории. Использовались общенаучные методы (анализ, синтез, сравнение, обобщение, индукция, дедукция), специальные исторические (историко-генетический, историко-сравнительный, историко-системный, биографический), а также институциональный методы.

Объектом исследования является внешнеполитическая деятельность Белорусской ССР.

Предметом исследования выступают отношения БССР с ЕЭК (их организационные основы, направления и методы реализации, формы и содержание) в 1954-1964 гг.

Обзор историографии по теме. Европейская экономическая комиссия - одна из пяти региональных экономических комиссий $\mathrm{OOH}$. Став ее первоначальным членом, Белорусская ССР по мере своих возможностей и в условиях советской федерации содействовала укреплению международного экономического сотрудничества и пользовалась его плодами.

К 20-летию МИД БССР (1964) вышла монография его сотрудников, которая давала союзному читателю определенное представление о деятельности республики в ООН, в том числе в ЕЭК [1].

Министр иностранных дел БССР К. В. Киселев участвовал также в создании подготовленного в Москве труда о политике и дипломатии Советского Союза в ООН (1968). Представленная им с позиций апологетики советской внешней политики глава охватывает весь послевоенный период и основана на указанной монографии [2]. В учебном пособии, содержащем общую характеристику внешнеполитиче- 
ской деятельности БССР (2013), В. Е. Снапковский отмечает, что неопределенный политико-правовой статус БССР и УССР в составе СССР давал основания западным ученым в сфере международного права называть эти две союзные республики - учредители ООН «государствами особого рода», «полу- или квазигосударствами» [3].

Г. Г. Сергеева, один из авторов академического двухтомника «Нарысы гісторыі Беларусі» (1995), отметила начало работы сотрудника МИД БССР в составе Постоянного представительства СССР при Европейском отделении ООН в Женеве [4]; об этом пишет также В. Г. Шадурский в шестом томе «Гісторыі Беларусі» (2011) [5]. Указанные издания не содержат конкретного материала о деятельности республики в ЕЭК в период хрущевской «оттепели», но дают представление о контексте - развитии всех сфер общественной жизни, в том числе экономической. В своей докторской монографии Н. С. Воробей (1981) также не останавливался на этом сюжете [6]. Научное изучение более чем 70-летнего опыта сотрудничества с ЕЭК получило благоприятные перспективы в связи с рассекречиванием Архивом МИД Республики Беларусь документов периода хрущевской «оттепели».

Результаты исследования. Почти сразу после смерти И. В. Сталина началась трансформация внешней политики Советского Союза. На смену доктрине о неизбежности горячей войны пришла политика мирного сосуществования, нашедшая отражение и в деятельности Советского Союза в ЕЭК. В марте 1954 г. в Женеве состоялась 9-я сессия ЕЭК, куда была направлена и делегация Белорусской ССР в составе А. Е. Гуриновича (заместитель заведующего политическим отделом МИД, глава делегации), Г. Г. Чернущенко (первый секретарь политотдела, советник делегации), А. Н. Шельдова (третий секретарь политотдела, референт-переводчик). Будучи активным помощником союзной делегации в выполнении директив ЦК КПСС и правительства, делегация республики выступила с критикой печатного органа ЕЭК - «Обзора экономического положения Европы» в связи с тенденциозностью данных, относящихся к СССР, и в пропагандистском ключе ознакомила участников с состоянием и перспективами экономики республики. При этом белорусские делегаты подчеркивали наличие предпосылок для развития экономического сотрудничества, заинтересованность в установлении контактов с представи- 
телями западноевропейских стран и необходимость борьбы против дискриминационной политики США в области международной торговли. В предложениях, адресованных руководству республики, отмечалось, что в связи с решением ЦК КПСС от 4 марта 1954 г. об участии СССР в работе всех комитетов ЕЭК целесообразно установить, чтобы УССР и БССР также были представлены в отдельных комитетах ${ }^{1}$.

А. Е. Гуринович возглавил делегацию республики и на 10-й сессии ЕЭК. Он принял участие в обсуждении «Обзора экономического положения Европы за 1954 год», приведя ряд данных, характеризующих экономические успехи Советской Белоруссии, и подверг критике американскую политику сбыта сельскохозяйственных излишков в западноевропейские страны по демпинговым ценам. Помимо этого, дипломат безрезультатно поддерживал предложение делегации СССР о приглашении на сессию представителей ГДР и ФРГ, а также выступил по докладу Комитета по жилищному строительству. Комиссия не приняла проекта резолюции СССР, направленного на устранение препятствий в торговле между Востоком и Западом. По другим вопросам делегация БССР особой активности не проявляла ${ }^{2}$.

В ходе 11-й сессии ЕЭК в 1956 г. делегация под руководством министра финансов Ф. Л. Кохонова сделала заявление о том, что Белорусская ССР будет принимать участие в работе трех комитетов по сельскому хозяйству, жилищному строительству и лесоматериалам. На заседаниях комитетов республику представляли министр сельского хозяйства В. П. Заяш, председатель Комитета по делам строительства и архитектуры при Совете Министров БССР В. А. Король, министр лесной промышленности Ф. А. Самуйленко, а в качестве переводчиков выступили дипломаты В. В. Греков и В. С. Колбасин. Активность в дискуссиях белорусские делегаты не демонстрировали, присматриваясь к работе. В отчетах особо подчеркивалось, что в период пребывания за границей нарушений, роняющих достоинство гражданина СССР, не было. Признавалось, что в Белоруссии не полностью решены такие проблемы, как удобрение полей, известкование кислых почв, улучшение лугов и пастбищ и мелиорация земель. Вы-

\footnotetext{
${ }^{1}$ Отчет о работе МИД БССР за 1954 год // Архив МИД Респ. Беларусь. Ф. 907. Оп. 3. Д. 304. Л. $2-3,14$.

${ }^{2}$ Отчет о работе МИД БССР за 1955 год // Архив МИД Респ. Беларусь. Ф. 907. Оп. 3. Д. 327. Л. 55.
} 
ражалось пожелание, чтобы Комитет по жилищному вопросу уделял больше внимания организации обмена опытом и совместным техническим проектам, а республике было что показать: только в 1956 г. ее посетили делегации американских, итальянских, финских строителей. Ф. А. Самуйленко в докладной записке на имя К. В. Киселева отмечал, что апробированных ЦК КПБ и Совмином БССР или опубликованных в печати цифровых материалов делегация не имела, а в МИД СССР предупредили о недопустимости использования другой статистики. По этой причине пришлось «два раза выступать с коротенькими заявлениями общего характера» ${ }^{3}$.

Министр финансов Ф. Л. Кохонов, выступая с трибуны 12-й сессии ЕЭК (1957), подчеркнул ценность сотрудничества в вопросах лесовозобновления, рационального использования лесных ресурсов и лесоматериалов, внедрения в практику достижений химической науки. Глава белорусской делегации выразил заинтересованность в обмене информацией по добыче и потреблению торфа. Был признан интересным зарубежный опыт механизации и стандартизации в строительстве, а также использования в этой отрасли новых материалов, с которым делегация ознакомилась во время целевой поездки в Бельгию. Создание Общего рынка интерпретировалось как серьезная угроза для народов и экономики Западной Европы. Было высказано мнение, что эта экономическая база НАТО способствует углублению раскола Европы и возникновению в центре континента опасного очага беспокойства. Отметим, что в составе делегации были сотрудники МИД Б. В. Кудрявцев и В. С. Колбасин - в будущем видные дипломаты $^{4}$.

На сессии Комитета ЕЭК по лесоматериалам, которая сопровождалась посещением швейцарских предприятий, Ф. А. Самуйленко выступал по вопросам экспорта круглого леса и пиломатериалов хвойных пород, а также сотрудничества в области лесозаготовок и деревообработки. Белорусские эксперты рассчитывали, что развитие производства плит по западной технологии даст возможность республике сэкономить сотни тысяч кубометров древесины и расширить материальную базу строительства, сделать его более быстрым, эко-

\footnotetext{
${ }^{3}$ Отчет о работе МИД БССР за 1956 год // Архив МИД Респ. Беларусь. Ф. 907. Оп. 3. Д. 349. Л. $2,168,172,177$.

${ }^{4}$ Отчеты МИД БССР, делегаций БССР на международных конференциях за 1957 год // Архив МИД Респ. Беларусь. Ф. 907. Оп. 3. Д. 351. Л. 2-20.
} 
номичным и качественным, а также обеспечить мебельную промышленность дешевым и вместе с тем качественным сырьем. Перед началом форума председатель Комитета по жилищному вопросу В. А. Король и сотрудник Главного управления по делам архитектуры при Совете Министров БССР И. О. Левко совершили ознакомительную поездку во Францию.

Участниками двух сессий Комитета по сельскому хозяйству стали заместитель министра сельского хозяйства И. С. Молочко, директор Института мелиорации Академии сельскохозяйственных наук БССР С. Г. Скоропанов и эксперт-консультант МИД БССР Б. В. Кудрявцев. Они декларировали, что за 1956 г. валовой сбор льна и картофеля в республике увеличился на $24 \%$, молока - на $26 \%$ сахарной свеклы - на $42 \%$, избегая при этом обсуждения проблем и трудностей 5 .

Коллегия МИД БССР отмечала, что белорусские делегации в ЕЭК работали много и напряженно, в материалах особой нужды не испытывали, но кое-что пришлось заимствовать у союзной делегации. Были выдвинуты предложения об обсуждении в рамках $\mathrm{OOH}$ вопроса активизации деятельности ЕЭК, которую американцы стремятся свернуть, а также о предоставлении БССР права заключать внешнеторговые сделки. Коллегия приняла решение о создании в министерстве групп по отдельным организациям, в которых состояла республика $(\mathrm{OOH}, \text { ЕЭК, специализированные учреждения ООН })^{6}$.

В 1958 г. правительство Белорусской ССР заявило об участии в работе еще одного комитета (по электроэнергии), о чем Ф. Л. Кохонов информировал участников 13-й сессии ЕЭК, проходившей в атмосфере поиска конструктивных решений. Целый ряд важных резолюций был принят единогласно: о дальнейшем развитии контактов (один из соавторов - БССР), технической помощи, европейских проблемах энергетики, активизации работы Комитета ЕЭК по внешней торговле, рабочей программе ЕЭК на 1958-1959 гг. Без возражений была принята и резолюция о потребительских товарах, инициированная СССР, в которой международное сотрудничество в этой области рассматривались как одно из средств повышения уровня жизни. Де-

\footnotetext{
${ }^{5}$ Отчет о работе МИД БССР за 1957 год // Архив МИД Респ. Беларусь. Ф. 907. Оп. 3. Д. 367. Л. 134, 141, 161, 162.

${ }^{6}$ Протоколы заседания Коллегии МИД БССР за 1957 год // Архив МИД Респ. Беларусь. Ф. 907. Оп. 3. Д. 353. Л. 35, 59-61, 68.
} 
легация исходила из принципа, что решение экономических проблем следует искать не на путях разрыва экономических связей Западной Европы с социалистическими странами, а на основе развития устойчивых экономических отношений независимо от социально-экономических систем.

Во время сессий Комитета по жилищному вопросу, проходивших в Женеве и Риме, состоялись ознакомительные поездки: в Чехословакию, организаторы которой продемонстрировали крупнопанельное строительство в Братиславе и Готвальдове, а также в Италию. Белорусская ССР предоставила обзор жилищного строительства в республике, в том числе сельского, и данные о его финансировании.

В Комитете по лесоматериалам Ф. А. Самуйленко предложил, чтобы эксперты больше внимания уделяли рациональной разработке лиственных лесов, а также составили рекомендации относительно лучшего использования деловой лиственной древесины при переработке. На сессии Комитета по вопросам сельского хозяйства С. Г. Скоропанов, выступивший с докладом о развитии сельского хозяйства БССР за 40 лет, привел данные о росте посевных площадей, урожайности полей, развитии животноводства, льноводства, повышении механизации сельского хозяйства. Делегации БССР подробно характеризовали «непрерывно растущую» экономику Беларуси и на конкретных примерах - «кризисное» состояние экономики и «бедственное» положение трудящихся капиталистических стран, усугубляемое гонкой вооружений и ростом военных бюджетов, предлагая выход - широкое экономическое сотрудничество на принципах мирного сосуществования ${ }^{7}$.

Анализируя итоги участия в ЕЭК и ее органах в 1958 г., руководство МИД БССР отмечало слабую связь с АН БССР и Белорусским государственным университетом, а также недостаточную разработку вопросов экономики западных стран, в частности США, Англии и Франции. В связи с малочисленностью референтского состава МИД (10 оперативных работников, в то время как в МИД Украинской ССР их насчитывалось 26) специализация референтов по основным направлениям министерства проведена не была. К. В. Киселев, высоко оценив работу С. Г. Скоропанова в Комитете по сельскому хозяйству,

\footnotetext{
${ }^{7}$ Отчет о работе МИД БССР за 1958 год // Архив МИД Респ. Беларусь. Ф. 907. Оп. 3. Д. 390. Л. 93-94, 101-104, 118-119, 122-123.
} 
высказался за назначение его постоянным делегатом от республики в этой структуре; министр поставил также вопрос об участии БССР в рабочих группах комитетов ЕЭК. В дискуссии о представительских расходах на форумы комиссии (они составили в 1958 г. 5,5 тыс. руб.), инициированной членами коллегии А. Е. Астапенко и А. Н. Шельдовым, более убедительным оказался последний: часть продуктов приходилось брать у союзной делегации, «с этим пора кончать» ${ }^{8}$.

С 1959 г. Белорусская ССР участвовала в работе уже четырех комитетов ЕЭК: по сельскому хозяйству, лесоматериалам, жилищному вопросу, а также электроэнергии. Секретариат ЕЭК в ответ на свой запрос относительно создания общеевропейской региональной торговой организации получил положительный ответ Минска: это будет способствовать более широкому товарообмену между европейскими странами в интересах их дальнейшего экономического прогресса и укрепления мира. Первым представителем республики, принявшим участие в работе Комитета по электроэнергии, стал Н. К. Заморин, директор «Белэнергопроекта», который поддержал поиски подходов к решению проблемы ее рационального потребления 9 .

В начале работы 14-й сессии ЕЭК (1959 г.) обсуждался уже не новый для комиссии вопрос о членстве ГДР. Глава делегации республики Ф. Л. Кохонов выразил твердую убежденность, что ГДР может сыграть заметную роль в расширении экономического и научно-технического сотрудничества, однако не нашел поддержки большинства. Делегация предложила Комитету по сельскому хозяйству предусмотреть в плане работы широкий обмен опытом и научными достижениями в области борьбы с туберкулезом скота. Эта инициатива была внесена в годовой доклад ЕЭК Экономическому и социальному совету ООН. Совместно с делегациями Бельгии, Польши и США была инициирована резолюция о проблемах борьбы с загрязнением вод в Европе, принятая единогласно. В целях более убедительной пропаганды экономических достижений БССР состоялся дипломатический прием, на котором присутствовало около 200 иностранных делегатов и гостей.

\footnotetext{
8 Протоколы заседания Коллегии МИД БССР за 1958 год // Архив МИД Респ. Беларусь. Ф. 907. Оп. 3. Д. 375. Л. 33, 62, 75, 106.

${ }_{9}^{9}$ Отчет о работе МИД БССР за 1959 год // Архив МИД Респ. Беларусь. Ф. 907. Оп. 3. Д. 405. Л. $3,11,15-17,53$.
} 
Коллегия МИД в 1959 г. отметила препятствия, которые чинились властями принимающей стороны (в частности, Италии) делегациям социалистических стран во время их ознакомительных поездок по линии ЕЭК: «нам ничего не хотят показывать». По распоряжению союзного внешнеполитического ведомства состав делегации на 14-ю сессию ЕЭК был сокращен до трех человек, в то время как делегация УССР состояла из пяти. К. В. Киселеву поручалось поставить перед МИД СССР вопрос о предварительных совещаниях трех советских делегаций, где можно было бы распределить ведущие вопросы, а также договориться о выступлениях по другим пунктам повестки дня, аргументации и тактике.

Министр высказал намерение обсудить в Центральном комитете Коммунистической партии Белоруссии (ЦК КПБ) потенциал печати, радио и телевидения для информирования населения о деятельности республики в ЕЭК. Коллегия приняла решение о привлечении к разработке инициативных предложений для рабочих органов ЕЭК экспертов из Института экономики АН БССР, министерств строительства, сельского хозяйства, Управления энергетики Совнархоза БССР, Госплана БССР.

Первый секретарь А. Н. Шельдов был откомандирован в Постоянное представительство СССР при Европейском отделении ООН на должность второго секретаря ${ }^{10}$.

15-я сессия ЕЭК (1960 г.) прошла, по оценке белорусской делегации, под флагом советских предложений: об изучении возможности совместного проектирования и строительства промышленных объектов, исследованиях экономических аспектов разоружения, созыве совещания министров внешней торговли европейских стран, дальнейшем расширении сотрудничества по обмену научным и техническим опытом.

Глава делегации Белорусской ССР Ф. Л. Кохонов полностью поддерживал предложения Москвы, а в выступлении по «Обзору экономического положения Европы» подверг критике составителей за недоброкачественную подготовку материалов, особенно в отношении социалистических стран. В издании отмечалось, что республика не пережила «промышленного взлета», а это, по оценке министра фи-

\footnotetext{
10 Протоколы заседания Коллегии МИД БССР за 1959 год // Архив МИД Респ. Беларусь. Ф. 907. Оп. 3. Д. 389. Л. 9, 104, 107, 126.
} 
нансов, «явно противоречило хорошо известным фактам ${ }^{11}$. Делегация СССР внесла предложение об изменении порядка составления обзоров путем привлечения правительственных экспертов стран - участниц ЕЭК и направления тематики издания странам-участницам на отзыв. Белорусские ученые и чиновники высшего и среднего звена (В. А. Король, А. А. Куцак, В. А. Левко, Н. А. Сазонов, С. Г. Скоропанов) стали участниками ознакомительных поездок ЕЭК в Скандинавию (строительство жилья), Австрию (опыт лесозаготовок), Францию и Румынию (рациональное использование электроэнергии) ${ }^{12}$.

Многократный участник форумов ЕЭК Б. В. Кудрявцев на одном из заседаний коллегии высказал мнение, что «самым больным вопросом в республике в связи с участием ее в ЕЭК является недостаточная отдача этого участия в нашем народном хозяйстве. Если мы успешно справляемся с политическим аспектом - показ нашего опыта на международной арене, то обратное поставлено у нас неудовлетворительно». В целях реализации Постановления Совета Министров БССР (СМ БССР) «Об упорядочении рассмотрения в республике вопросов научно-технических связей с зарубежными странами» (1960 г.) коллегия приняла решение о создании объединенной комиссии из представителей организаций, заинтересованных в сотрудничестве с ЕЭК, а также рекомендовала ее руководству обобщить республиканский опыт для комитетов ЕЭК. МИД БССР внес предложение в ЦК КПБ и СМ БССР об участии республики в Комитете по внутреннему транспорту и группе по газу ${ }^{13}$.

В 1961 г. представители БССР приняли участие в работе 35 международных сессий, конференций, симпозиумов и совещаний в рамках ООН, в том числе 17 сессий по линии ЕЭК. В годовом отчете, направленном в ЦК КПБ, СМ БССР и МИД СССР, отмечалось, что МИД в сотрудничестве с Госкомитетом СМ БССР по координации научно-исследовательских работ намерен взять под постоянный контроль сбор информации по линии ЕЭК и внедрения всего ценного в народное хозяйство.

\footnotetext{
${ }^{11}$ Отчет о работе МИД БССР за 1960 год // Архив МИД Респ. Беларусь. Ф. 907. Оп. 3. Д. 428. Л. 15-16.

12 Свилас С. Ф. ЮНЕСКО в системе внешнеполитической деятельности Белорусской ССР (1954-1964 гг.) : дис. ... д-р ист. наук. Минск, 1018. С. 318-320.

${ }^{13}$ Протоколы заседания Коллегии МИД БССР за 1960 год // Архив МИД Респ. Беларусь. Ф. 907. Оп. 3. Д. 413. Л. 12, 16-17, 49, 92-93.
} 
Количественный состав делегации на очередную, уже 16-ю, сессию ЕЭК оставался прежним - 4 человека, в него был включен в качестве советника А. Н. Шельдов, занимавший должность второго секретаря Представительства СССР при Европейском отделении ООН. Руководитель делегации Ф. Л. Кохонов заявил, что ЕЭК сделала еще далеко не все, что она в действительности может сделать для выполнения поставленных перед ней задач, в частности, в вопросах автоматизации, химии, нефти, машиностроения. Работа форума совпала с первым в истории человечества полетом человека в космос, и Ф. Л. Кохонов призвал ЕЭК заняться решением вопросов расширения и развития связей между странами с различными социально-экономическими системами.

Осветив достижения в жилищном строительстве, делегация высказалась за более глубокое изучение вопросов планирования и застройки городов, усиление обмена информацией на многосторонней и двусторонней основе. Участие в сессии убедило в необходимости более глубокого изучения документов ЕЭК и заблаговременной подготовки проектов выступлений ${ }^{14}$.

Сессия рабочей группы по сельской электрификации, в которой принял участие академик Н. А. Сазонов, сопровождалась ознакомительной поездкой по ФРГ, во время которой советские специалисты пользовались «доброжелательным отношением со стороны организаторов, а также случайных людей». По предложению представителя Австрии сессия в девятый раз избрала своим председателем Н. А. Сазонова, что подтверждает его международный авторитет. Деловая обстановка сессии была омрачена инцидентом, когда американская делегация не пригласила глав делегаций Украины и Белоруссии на обед, при этом советник делегации США заявил, что его страна не рассматривает УССР и БССР в качестве независимых и самостоятельных участников. В результате делегация СССР отказалась от американского предложения.

После командировки в Женеву на сессию специализированной рабочей группы начальник Главного управления по газификации промышленности СМ БССР В. А. Толмачев предложил создать в Советском Союзе единый центр по руководству газовой отраслью, что

\footnotetext{
${ }^{14}$ Отчет о работе МИД БССР за 1961 год // Архив МИД Респ. Беларусь. Ф. 907. Оп. 3. Д. 453. Л. 5, 23, 40-45, 106-108.
} 
способствовало бы решению ряда технических проблем газовой промышленности СССР в целом и Белоруссии в частности. Он отметил, что работа делегации Белорусской ССР проходила в тесном контакте с делегациями стран соцлагеря и под непосредственным руководством делегации СССР.

С. Г. Скоропанов, отчитываясь перед коллегией за поездку в Женеву, предложил устраивать там ежегодные приемы и пригласить в республику группу иностранных экспертов. Он принял от К. В. Киселева поручение выступить в печати со статьей о тяжелом положении фермеров в капиталистических странах. Участника конференции по вопросам борьбы с загрязнением вод в Европе Ф. Д. Прокудина обязали подготовить докладную записку на имя первого секретаря ЦК КПБ К. Т. Мазурова и председателя СМ БССР Т. Я. Киселева с конкретными предложениями о подходах к решению этой проблемы в республике, а Государственный комитет по охране природы - регулярно направлять в ЕЭК (через МИД) информацию о проводимых акциях. Ф. А. Самуйленко, делясь своими впечатлениями о поездках во Францию и Англию, дал критическую оценку состояния целлюлозной промышленности на родине ${ }^{15}$.

Белорусскую делегацию на 17-й сессии ЕЭК (1962) возглавил заместитель министра иностранных дел А. Е. Гуринович, а советник делегации А. Н. Шельдов получил к этому времени повышение, став первым секретарем Постоянного представительства СССР при Европейском отделении $\mathrm{OOH}(\mathrm{EO} \mathrm{OOH})$.

Делегация выступила 14 раз, А. Е. Гуринович и А. Н. Шельдов участвовали в работе комитета по резолюциям, причем республика стала соавтором двух таких документов. Резолюция «Об обеспечении аналитическими аннотациями научных документов в области прикладной экономической теории» (первоначальный вариант был предложен делегацией Польши) призывала расширять обмен научно-технической информацией, а резолюция «Об организации сессий ЕЭК» (инициатива группы западных стран) поручила исполнительному секретарю упорядочить работу в этом направлении.

По-прежнему в выступлениях делегатов БССР пропагандировались экономические успехи республики как пример того, чего может

\footnotetext{
15 Протоколы заседания Коллегии МИД БССР за 1961 год // Архив МИД Респ. Беларусь. Ф. 907. Оп. 3. Д. 436. Л. 33-37, 59-67, 77.
} 
добиться народ, «вдохновленный величественным планом построения коммунизма».

На сессию Комитета по сельскому хозяйству был направлен академик И. С. Лупинович, отметивший сдержанное отношение дипломатов стран - участниц Европейского экономического сообщества к обмену научно-технической информацией с Восточной Европой. Он заявил, что политика стран ЕЭС направлена на искусственное создание самообеспечения сельскохозяйственными продуктами внутри сообщества в ущерб нормальному развитию торговли между Востоком и Западом. Академик выступил за расширение обмена технической информацией и опытом в области механизации и рационализации сельскохозяйственного производства, в частности, посредством кинематографа. В совещании экспертов по рационализации сельского хозяйства участвовал И. Р. Размыслович, заведующий кафедрой Института механизации сельского хозяйства.

После командировки на симпозиум по вопросам рационализации потребления электроэнергии, проходивший в Варшаве, делегат Я. Х. Ботвинник сделал вывод об отставании республики в этой области, пассивности институтов экономики и энергетики АН БССР, дефиците кадров инспекторов. Делегат предложил изучать и использовать польский опыт. Сессия Комитета по электроэнергии с участием академика Н. А. Сазонова сопровождалась ознакомительной поездкой в Финляндию и Швецию.

Участник сессии Комитета по жилищному вопросу В. А. Король совершил ознакомительную поездку в Англию и Ирландию, а на семинар по вопросам политики в области градостроения и планирования городов был командирован главный архитектор Минска А. И. Наконечный.

В соответствии с указаниями МИД СССР и Государственного комитета СМ СССР по делам строительства (Госстроя) делегат «осуществлял полноценный показ» достижений республики. После совещания экспертов Комитета по жилищному вопросу директор института «Минскпроект» И. И. Левко признал, что трудовые затраты на стройплощадках Советского Союза выше, чем в ряде западноевропейских стран и Чехословакии, особенно велика разница в кирпичном строительстве. Он рекомендовал изучать также зарубежный опыт по снижению расходов на содержание и ремонт зданий. 
Исключительно идеологическую направленность имело участие директора Института экономики АН БССР Г. Г. Ковалевского в совещании старших советников по экономическим вопросам. Он предпринял попытку убедить западных экономистов в преимуществах плановой экономики социализма, но об отклике на свое выступление умолчал. После возвращения с сессии Группы экспертов по изучению проблем создания единой сети европейских внутренних водных путей международного значения сотрудник главного управления речного флота при СМ БССР В. Д. Артамасов обратил внимание на необходимость согласования деятельности НИИ и проектных организаций СССР с учреждениями республики (создание Днепро-Виленского бассейна происходило, в основном, по БССР $)^{16}$.

Делегации СССР, БССР и УССР, проанализировав итоги сессии Комитета по газу, внесли конкретные предложения, направленные на достижение намеченного уровня добычи и использования природного и сжиженного газа в СССР. На сессии Комитета по лесоматериалам БССР была представлена директором Минского леспромхоза Е. Ф. Нечергиным, который высказал мнение, что в условиях республики, недостаточно богатой спелыми лесами, нужно уделить больше внимания быстрорастущим породам древесины с целью обеспечения деревообрабатывающей и бумажной промышленности сырьем. БССР интересовал зарубежный опыт в области лесозаготовки, деревообработки, бумажной и целлюлозной промышленности. В целом участие БССР в 17-й сессии ЕЭК и 11 ее технических органов было оценено руководством МИД республики как весьма продуктивное ${ }^{17}$.

На 18-й сессии ЕЭК ООН (1963 г.) главой делегации вновь был утвержден заместитель министра иностранных дел А. Е. Гуринович. Делегат А. Н. Шельдов составил аналитическую справку «Экономический рост в европейских странах. 1949-1959 гг.»- добротное подспорье для белорусских участников. Члены делегации выступили 14 раз, республика стала соавтором четырех резолюций, направленных на расширение европейского экономиического и научно-технического сотрудничества. Делегация ориентировала комиссию на оказание помощи и содействия экономическому развитию слаборазвитых

\footnotetext{
${ }^{16}$ Отчет о работе МИД БССР за 1962 г. // Архив МИД Респ. Беларусь. Ф. 907. Оп. 3. Д. 480. Л. 7, 110-121, 132, 137-148, 152.

17 Протоколы заседания Коллегии МИД БССР за 1962 год // Архив МИД Респ. Беларусь. Ф. 907. Оп. 3. Д. 459. Л. 20, 39-41.
} 
стран и настаивала на дискуссии о неудовлетворительном использовании взносов Белорусской ССР в расширенную программу технической помощи, Специальный фонд и Фонд помощи детям. В Минске был проведен лишь один семинар по линии Продовольственной и сельскохозяйственной организации ООН (ФАО) для специалистов из слаборазвитых стран по вопросам производства молочных продуктов (1962).

По оценке делегации, усилия ЕЭК в области подготовки технических кадров для ускоренной индустриализации развивающихся стран были явно недостаточны, учебные заведения республики в этих целях не использовались. В «Обзоре экономического положения Европы» по-прежнему отсутствовали данные об итогах хозяйственного развития БССР.

В течение года сотрудники министерства разработали и представили на рассмотрение МИД СССР инициативные предложения к очередной сессии ЕЭК, а также по программе Комитета по лесоматериалам и структуре Комитета по газу.

Исполнительному секретарю ЕЭК были направлены предложения об улучшении деятельности комиссии, материалы по БССР для «Обзора жилищной политики европейских стран за 1961-1962 гг.»; в Женеву регулярно посылались статистические данные и другие материалы по вопросам научно-технического сотрудничества в рамках $\mathrm{E} Э \mathrm{~K}^{18}$.

Коллегия МИД (1963) руководствовалась документами ноябрьского Пленума ЦК КПСС (1962) об усилении использования зарубежного опыта в экономике и полностью одобрила работу делегации республики на 18-й сессии ЕЭК. При этом была дана неудовлетворительная оценка союзной делегации, которая «должна помогать республикам, а не тормозить их работу», о чем Минск поставил в известность союзный МИД.

Государственный комитет по строительству (Госстрой) получил задание дважды в год информировать республиканское внешнеполитическое ведомство об использовании зарубежного опыта и выдвигать инициативные предложения. Была особо подчеркнута ценность зарубежного опыта в области продуктивности лесов, лесозаготовок,

${ }^{18}$ Отчет о работе МИД БССР за 1963 г. // Архив МИД Респ. Беларусь. Ф. 907. Оп. 3. Д. 505. Л. 7-8, 51-60. 
деревообработки, целлюлозно-бумажной промышленности, производства древесно-стружечных и древесно-волокнистых плит ${ }^{19}$.

19-я сессия ЕЭК ООН (1964) прошла в условиях некоторого ослабления международной напряженности, вызванного подписанием годом ранее Московского договора о запрещении испытаний ядерного оружия в атмосфере, космическом пространстве и под водой. Белорусскую делегацию возглавил заместитель председателя Госкомитета СМ БССР по координации научно-исследовательских работ Л. И. Федоров.

Он приветствовал наблюдателя от ГДР, которого в аппарате ЕЭК рассматривали лишь как посланца «восточной зоны», что вызвало протест семи социалистических стран. На форум прибыли также наблюдатели от Алжира, Индии, Кубы, ОАР, Израиля, Японии, Венесуэлы, представители многих международных организаций и учреждений.

Делегаты США стремились уменьшить значение сессии: одновременно в Женеве проходила учредительная сессия Конференции $\mathrm{OOH} \mathrm{по} \mathrm{торговле} \mathrm{и} \mathrm{развитию} \mathrm{(ЮНКТАД).} \mathrm{Позиция} \mathrm{Вашингтона} \mathrm{на-}$ шла поддержку у ряда делегаций, предлагавших сократить продолжительность форума, лимитировать выступления и не принимать резолюций, поскольку секретариат перегружен работой по реализации уже принятых документов.

Делегация БССР выступила 11 раз. По ее оценке, ЕЭК не занималась изучением и обобщением передового опыта, структура комиссии и особенно ее вспомогательных органов отвечала цели уже достигнутой - восстановление разрушенной Второй мировой войной экономики Европы.

В качестве перспективы рассматривалось изучение силами ЕЭК достижений химической науки и их внедрение в производство, при этом отмечалось, что в связи с реализацией программы химизации республика установила экономические и научно-технические контакты с фирмами и организациями Англии, Италии, Франции, ФРГ и ряда других стран.

Доклад исполнительного секретаря ЕЭК В. Велебита (Югославия) вызвал оживленную дискуссию. В выступлениях представи-

\footnotetext{
${ }^{19}$ Протоколы заседания Коллегии МИД БССР за 1963 год // Архив МИД Респ. Беларусь. Ф. 907. Оп. 3. Д. 486. Л. 48-49, 54, 189-190.
} 
телей Турции, ФРГ, Италии и США выдвигались требования ограничить компетенцию ЕЭК. Л. И. Федоров отметил, что республика всегда придавала большое значение деятельности этого органа, рассматривая его как европейский центр экономического и научно-технического сотрудничества стран с различными социально-экономическими системами, оказывающий серьезное влияние на международные экономические отношения.

Он указал, что решающим средством стимулирования торговли являются не отдельные технические, а радикальные меры, прежде всего устранение барьеров, ликвидация дискриминации и других преград в мировой торговле.

Глава делегации потребовал принятия мер, направленных на кардинальное улучшение работы по подготовке «Обзора экономического положения Европы», где БССР и УССР даже не упоминались. По оценке Л. И. Федорова, республика, ведущей отраслью которой стало машиностроение, являлась высокоразвитой в индустриальном отношении.

БССР выступила в качестве соавтора 5 из 15 принятых резолюций, первоначальные проекты которых были разработаны в МИД БССР и одобрены МИД СССР: долгосрочная программа ознакомительных поездок, деятельность комиссии в связи с Конференцией $\mathrm{OOH}$ по вопросам торговли и развития, проведение в жизнь Декларации о переводе на мирные цели средств и ресурсов, высвобождаемых в результате разоружения, долгосрочная программа работы совещаний старших советников по экономическим вопросам, проблемы энергетики в Европе.

Эти документы, по оценке советской дипломатии, ориентировали ЕЭК на развитие, углубление и расширение деятельности в области экономического, научно-технического и торгового сотрудничества.

Делегаты социалистических стран на сессиях Комитета ЕЭК по сельскому хозяйству (от Белорусской ССР в Женеву выезжал академик И. С. Лупинович) продолжали настаивать на усилении работы комитета в направлении химизации этой отрасли экономики. В решениях форума нашли отражение внесенные белорусским делегатом предложения о включении вопроса механизации внесения удобрений в программу рабочей группы комитета. 
По инициативе представителей СССР, УССР и БССР секретариату поручалось подготовить детальный проект долгосрочной рабочей программы комитета, включив в него вопросы обмена технической информацией, повышения плодородия почв и продуктивности животноводства, хранения фруктов и овощей. Академик отметил неблагоприятные погодные условия весны-лета 1964 г. в БССР, которые сказались на урожайности.

По предложению И. С. Лупиновича комитет принял решение о включении в программу рабочей группы вопросов механизации сельского хозяйства, транспортировки продукции и применения минеральных удобрений.

По поручению президиума сессии белорусский академик составил письмо с предложением странам - членам ЕЭК организовать международное сортоиспытание, обмен сортовыми семенами и посадочным материалом.

Заместитель начальника Главного управления энергетики и электрификации при СМ БССР В. И. Овчинников представлял БССР на сессии Комитета по электроэнергии. По вопросу проведения исследования относительно объединения энергосистем европейских стран состоялась острая дискуссия с его участием. Капиталистические страны, за исключением Австрии, возражали против постановки этого вопроса, ссылаясь на отсутствие доверия между Западом и Востоком.

На сессии Комитета по жилищному вопросу, строительству и градостроительству ЕЭК, проходившей в Вашингтоне, республику вновь представлял В. А. Король. Представительство БССР при ООН в Нью-Йорке оказало ему помощь, направив первого секретаря представительства И. Т. Стельмашонка.

Критикуя предложение делегации Нидерландов о росте жилищного строительства путем увеличения численности занятых, советские участники видели решение проблемы посредством индустриализации, развития государственного сектора и усиления государственного контроля над частным сектором, а также укрупнения и специализации строительных организаций. По предложению советских делегаций было принято решение передать на рассмотрение соответствующим органам $\mathrm{OOH}$ вопроса о целесообразности проведения межрегионального семинара по вопросам строительства. 
В. А. Король обратил внимание на растущую роль электронных вычислительных машин в отрасли и предложил наладить обмен опытом по этому вопросу. При рассмотрении долгосрочной программы ознакомительных поездок он предложил республику в качестве принимающей стороны и стал участником ознакомительной поездки по северо-западной части США.

Поездка показала, что в организации строительства там имелись «положительные моменты», которые могли найти применение в республике (например, строительство школьных бассейнов), при этом американцы «ухватились» за предложение строить дома из кабинкомнат $^{20}$.

Коллегия МИД, обсудив вопрос об участии республики в 19-й сессии ЕЭК и в целях улучшения подготовки к дальнейшим форумам, приняла решение активнее привлекать к сотрудничеству Госкомитет по координации научно-исследовательских работ при СМ БССР. Она обратилась в ЦК КПБ с предложением поручить Институту экономики АН БССР дать анализ «Обзоров экономического положения Европы», а также поручила ОМЭО МИД БССР подготовку к очередной сессии ЕЭК.

В 1964 г. на заседаниях коллегии отмечалось, что, поскольку СССР, УССР и БССР не участвуют в ФАО, особое значение имеет опыт, полученный в Комитете по сельскому хозяйству (специализация и снижение себестоимости сельскохозяйственной продукции, экономическая эффективность капиталовложений, целесообразность производства некоторых продуктов), который, однако, использовался слабо.

Результатом внедрения опыта жилищного строительства в Швеции, Англии, Чехословакии стали микрорайоны в Минске, Гомеле, Могилеве, Витебске, возрастание доли трехкомнатных квартир при незначительном увеличении их общей площади. Руководителей самой молодой тогда в республике газовой отрасли заинтересовал зарубежный опыт подземного хранения газа и использования этого топлива в химической промышленности.

На июльском заседании коллегии с отчетом о работе в качестве второго секретаря Постоянного представительства СССР при ЕО

\footnotetext{
${ }^{20}$ Отчет о работе МИД БССР за 1964 г. // Архив МИД Респ. Беларусь. Ф. 907. Оп. 3. Д. 529. Л. 8, 12-13, 157-182, 190-192, 196-202, 311.
} 
ООН выступил Э. И. Борщевский, сменивший А. Н. Шельдова. Успев принять участие в нескольких форумах ЕЭК, он выделил проблемы: нехватка кинофильмов и печатной продукции о республике, слабая оперативность Минска в направлении информации, отсутствие автомобиля.

Участники заседания обратили внимание, что Украинская ССР получила в представительстве должность советника, и приняли решение ходатайствовать перед МИД СССР о переводе Э. И. Борщевского на должность первого секретаря. Сотрудник МИД Л. А. Долгучиц предложил также поставить вопрос перед партийным руководством и правительством республики о создании Постоянного представительства БССР при Европейском отделении ООН в Женеве.

На заседаниях коллегии по-прежнему обсуждались вопросы укрепления межведомственного взаимодействия, внесения инициативных предложений не только политического, но прежде всего практического характера, преемственности в формировании делегаций, улучшения их подготовки и качественного анализа проделанной работы, увеличения количества и повышения эффективности ознакомительных поездок. В ЦК КПБ и СМ БССР было внесено предложение о закреплении органов ЕЭК за соответствующими министерствами и ведомствами. Руководство республики утвердило также предложение МИД БССР о передаче ряда функций по обеспечению участия представителей республики в технических органах ЕЭК Госкомитету СМ БССР по координации научно-исследовательских работ.

Только за 1964 г. специалисты республики приняли участие в 21 совещании по линии ЕЭК. Наиболее эффективно осуществлялось сотрудничество в рамках Комитета по электроэнергии и Комитета по газу. Недостаточно оперативно рассматривались вопросы взаимодействия с Женевой Госстроем БССР, Министерством сельского хозяйства и Управлением лесной, бумажной и деревообрабатывающей промышленности СНХ БССР.

Руководство МИД республики выражало обеспокоенность отсутствием белорусских представителей в аппарате ЕЭК ${ }^{21}$. Вместе с тем в 1968 г. состоялась ознакомительная поездка в республику участников сессии Комитета ЕЭК по жилищному вопросу, что свиде-

${ }^{21}$ Протоколы заседания Коллегии МИД БССР за 1964 год // Архив МИД Респ. Беларусь. Ф. 907. Оп. 3. Д. 513. Л. 32-33, 72-78, 99-101, 124-131. 
тельствовало о международном признании опыта в этой отрасли экономики ${ }^{22}$.

Выводы. Деятельность Белорусской ССР в ЕЭК значительно активизировалась в условиях либерализации советского политического режима и реализации реанимированного Н. С. Хрущевым ленинского принципа мирного сосуществования. Координатором усилий республики в международном экономическом сотрудничестве выступало министерство иностранных дел, которое привлекало к взаимодействию с комиссией заинтересованные республиканские органы, однако требуемое межведомственное взаимодействие достигнуто не было.

К середине 1960-х гг. Белорусская ССР накопила определенный опыт работы в ЕЭК и ее структурах, занимавшихся вопросами сельского хозяйства, лесоматериалов, жилищного строительства, электроэнергии, газовой промышленности, европейской статистики.

С 1959 г. в составе Представительства СССР при ЕО ООН стал работать белорусский дипломат (сначала А. Н. Шельдов, затем Э. И. Борщевский), в 1963 г. был создан отдел международных экономических организаций, первым руководителем которого стал А. Н. Шельдов. В оперативных и исследовательских отделах Секретариата ЕЭК белорусские эксперты отсутствовали, республика не принимала сотрудников аппарата и делегации стран - членов комиссии, однако уже предложила свою площадку для обмена опытом.

Членство в ЕЭК осуществлялось в условиях партийно-государственной монополии на международные связи и слегка приподнятого «железного занавеса». МИД БССР руководствовался указаниями ЦК КПБ (первый секретарь К. Т. Мазуров, секретарь П. М. Машеров), а решения по вопросам сотрудничества республики с комиссией принимались после согласования с союзным Центром - ЦК КПСС и МИД СССР.

Белорусская ССР в рассматриваемый период участвовала, по подсчетам автора, в 115 международных конференциях, совещаниях и поездках по линии ЕЭК, но делегации были малочисленны (от 1 до 4 человек); в среднем ежегодно выезжало не более 15 специалистов, не считая дипломатов.

${ }^{22}$ Тихонов О. А. Участие Белорусской ССР в деятельности экономических органов ООН (1945-1983 гг.) : автореф. дис. ... канд. ист. наук. Минск : Ин-т истории АН БССР, 1984. С. 9. 
Деятельность в ЕЭК способствовала формированию в республике «человека международного», выходящего в своем сознании за пределы БССР и Советского Союза.

Белорусская ССР являлась одновременно субъектом международных отношений и субъектом советской федерации, ее активность в международных организациях регулировалась союзным Центром. Республика играла значительную роль в осуществлении директив Москвы, поощрявшей выдвижение Минском инициатив по экономическому сотрудничеству, и в основном поддерживала их.

Вместе с тем имели место жалобы сотрудников МИД БССР на низкие заработную плату и представительские расходы, статус белорусского дипломата в Постоянном представительстве СССР при ЕО ООН, сокращение состава делегаций, отсутствие консультаций или промедление с ними.

Для риторики делегатов республики и информации, направляемой в Женеву, были характерны «съездовский синдром», излишняя насыщенность цифрами, вертикальный и горизонтальный компаративизм, замена аргументации пропагандистскими шаблонами.

К середине 1960-х гг. ЕЭК превратилась в один из приоритетов во внешнеполитической деятельности БССР. По подсчетам автора, в 1954-1964 гг. БССР направила делегатов на 335 международных сессий, конференций, симпозиумов, совещаний, стажировок, поездок, из них 115 - по линии ЕЭК, 75 - ЮНЕСКО, 23 - МАГАТЭ, 16 - МОТ. Реализуя членство в ЕЭК, республика заявила о себе как об активном субъекте международных отношений. Членство в комиссии служило не только инструментом пропаганды достижений республики, но и источником дипломатического опыта, предпосылкой создания кадровой базы для решения задач внутреннего экономического развития и дальнейшей активизации внешнеполитической деятельности.

\section{Библиографические ссылки}

1. Белорусская ССР на международной арене / Министерство иностранных дел Белорусской ССР; под ред. К. В. Киселева. М. : Междунар. отношения, 1964. 335 с.

2. Киселев K. В. Белорусская ССР в $\mathrm{OOH} / /$ Советский Союз и Организация Объединенных Наций (1945-1965 гг.) / под ред. В. Л. Исраэляна. М. : Наука, 1968. С. 429-460.

3. Снапковский B. Е. История внешней политики Беларуси : пособие. Минск : БГУ, 2013. 495 c.

4. Нарысы гісторыі Беларусі : у 2 ч. / М. П. Касцюк [i інш.] ; Ин-т гісторыі АНБ. Мінск: Беларусь, 1995. Ч. 2 . 560 с. 
5. Гісторыя Беларусі : у 6 т. / рэдкал.: М. Касцюк (гал. рэд.) [i інш.]. Минск : Соврем. шк. Экоперспектива, 2007-2011. Т. 6 : Беларусь у 1946-2009 гг. / Л. Лыч [і інш.]. 2011. 728 с.

6. Воробей Н. С. Участие Белорусской ССР в отношениях Советского Союза с капиталистическими странами. Минск : Наука и техника, 1981. 246 с.

Дата поступления статьи: 4.09.2019.

Образец цитирования: Свилас С. Ф. Деятельность Белорусской ССР в Европейской экономической комиссии (1954-1964 гг.) // Актуальные проблемы международных отношений и глобального развития : сб. науч. ст. Минск, 2018. Вып. 7. С. 46-70.

Автор: Свилас Светлана Францевна - доктор исторических наук, профессор кафедры международных отношений Белорусского государственного университета; e-mail: svilas@ tut.by.

\title{
ACTIVITIES OF THE BYELORUSSIAN SSR IN THE EUROPEAN ECONOMIC COMMISSION (1954-1964)
}

\author{
S. F. Svilas \\ Belarusian State University, Minsk, Republik of Belarus
}

\begin{abstract}
For the first time in historiography, based on the documents of the Archive of the Ministry of Foreign Affairs of the Republic of Belarus, a comprehensive study of the activities of the Byelorussian SSR in the Economic Commission for Europe during the Khrushchev Thaw, when the foreign policy activity of the republic significantly increased, was conducted. Being a subject of international relations, the Byelorussian SSR at the same time continued to remain a subject of the Soviet Federation. The participation of the republic in the sessions of the ECE and its Committees (on agriculture, timber, housing, electricity, gas, statistics), as well as the evaluation of the results by the Board of the Ministry of Foreign Affairs of the republic, are considered.

Particular attention is paid to the efforts of Minsk to form the institution of the Permanent Representative of the BSSR to the UN European Office, the role of government agencies, primarily the Ministry of Foreign Affairs, and their individual representatives in the development of international economic cooperation. The decisionmaking mechanism on relations with the ECE at the republican level and the influence of the All-Union Center on it are disclosed.

The place and role of the ECE in the system of the foreign policy of the BSSR are shown, the significance of the Commission in the activities of the republican Foreign Ministry and the international activity of other ministries and departments is determined. On the example of ECE multilateral diplomacy and the participation of the
\end{abstract}


Byelorussian SSR, the particularities of the implementation of the principle of peaceful coexistence of two socio-political systems in the economic sphere are described.

The problems, difficulties, and results of the republic's participation in the ECE during the specified period are considered. It was emphasized that the membership of the BSSR in the Commission was primarily pragmatic, which prevailed over the propaganda aspect, but in the conditions of the Cold War and the Soviet economic system, the potential of international cooperation in this area was far from being fully realized.

Key words: USSR; Byelorussian SSR; European Economic Commission; Khrushchev Thaw; international economic cooperation; economic diplomacy; Soviet Federation; subject of the Soviet Federation; subject of international relations; developing countries.

\section{References}

1. Kiselev, K. V. (Ed.). (1964). Belorusskaya SSR na mezhdunarodnoy arene. [Belarusian SSR in the international arena]. In: Ministry of Foreign Affairs of the Belarusian SSR. Moscow, Intern. relations, 335 p. (In Russ.).

2. Kiselev, K. V. (1968). Belorusskaya SSR v OON [Belorussian SSR at the UN]. In: Soviet Union and United Nations Organization (1945-1965). Moscow, Nauka, p. 429-460. (In Russ.).

3. Snapkovskiy, V. E. (2013). Istoriya vneshney politiki Belarusi: posobiye [History of Belarus Foreign Policy: A Handbook]. Minsk, BSU, 495 p. (P. 361). (In Russ.).

4. Kasciuk, M. P. (Etc.). (1995) Narysy historyi Bielarusi : u 2 č. [Essays stories of Belarus: 2 parts]. Minsk: Belarus, Part 2, 560 p. (P. 409-419). (In Belaruss.).

5. Kasciuk, M. P. (Ed.). (2007-2011). Historyja Bielarusi: u 6 t. [History of Belarus: 6 v.]. Minsk: Minsk, Ekoperspektiva, 728 p. (P. 225-227, 235, 309-311, 323, 699). (In Russ.).

6. Vorobei, N. S. (1981). Uchastie Belorusskoj SSR v otnoshenijach Sovetskogo Sojuza s kapitalisticheskimi stranami [Participation of the Byelorussian SSR in the relations of the Soviet Union with capitalist countries]. Minsk, Science and technology, 246 p. (In Russ.).

Received: 4.09.2019.

For citation: Svilas, S. (2019). Activities of the Byelorussian SSR in the European Economic Commission (1954-1964). In: Actual problems of international relations and global development: collection of scientific papers. Minsk, Vol. 7, p. 46-70.

About author: Svilas Svetlana - Doctor of Historical Sciences, Professor of the International Relations Department, Belarusian State University; e-mail: svilas@tut.by. 